Portland State University

PDXScholar

\title{
Black Gold, White Gold, and the Bear's Influence Over Central Asian Economies
}

Jennifer Leo

Portland State University

Follow this and additional works at: https://pdxscholar.library.pdx.edu/honorstheses

Part of the Asian History Commons, European History Commons, and the European Languages and Societies Commons

Let us know how access to this document benefits you.

\section{Recommended Citation}

Leo, Jennifer, "Black Gold, White Gold, and the Bear's Influence Over Central Asian Economies" (2021). University Honors Theses. Paper 985.

https://doi.org/10.15760/honors.1009

This Thesis is brought to you for free and open access. It has been accepted for inclusion in University Honors Theses by an authorized administrator of PDXScholar. Please contact us if we can make this document more accessible: pdxscholar@pdx.edu. 
Black Gold, White Gold, and the Bear's Influence over Central Asian Economies

Jennifer Leo

Portland State University 
In examining the socioeconomic state of former Soviet republics in Central Asia, it becomes clear that the current economies of nations such as Kazakhstan, Uzbekistan, and Kyrgyzstan have been shaped by a history of Russian dominance, followed by turbulent developments that took place during the "perestroika" and post-independence period. These periods were marked by significant changes in governance which allowed Central Asian nations to gain inclusion in the global economy, forge partnerships with economically thriving world superpowers (US and China), and emerge from the Soviet system of mono-product economies. As a result of such developments, former republics of the Soviet Union experienced, and continue to experience, continuities and ruptures within their steadily expanding economies. This thesis will trace these developments by applying a chronological approach and comparative method.

Due to the fact that Russian colonialism in the 19th century played such a quintessential role in laying the foundations for Soviet hegemony over Central Asian republics, it is necessary to firstly characterize the empire. Established in 1721 and remaining under the rule of the Romanov family until its violently forced dissolution in 1917, the Russian empire quickly rose to power as the Swedish and Ottoman empires went into a decline. At the turn of the 20th century, Russia began an inevitable shift towards industrialization. However, poverty and the mistreatment of rural peasants (an affliction that would be largely transferred to the people of Soviet Central Asia) were still rampant and resulted in public discontent against Tsar Nikolai II and wealthy landowners. This small percentage of people were also bitterly referred to as bourgeoisie. In 1917, the tsarist government would be overthrown by Bolsheviks and replaced with the Union of Soviet Socialist republics in 1922. Correspondingly, Russia's bourgeoisie was almost entirely eliminated as class through means of land confiscation and executions during the Red Terror of 1918 (Blakemore, 2020). 
Despite the removal of the tsar and dissolution of mass class disparities, a new form of hegemony was on the horizon. Namely, Russian economic, political, and cultural hegemony within the frameworks of the newly established Soviet Union. The term 'hegemony' was initially coined by the Italian Marxist philosopher, Antonio Gramsci, in order to describe the dominance of a social group or government entity over others. In fact, many of Gramsci's writings were actually inspired by the Bolshevik Revolution, as the philosopher struggled with Italy's own oppressive government. Similarly to Gramsci, many observers and active participants in the formation of the Soviet Union were optimistic about Lenin's idea of a utopian socialist society---a radical admission which was supplemented by propaganda that portrayed comradeship between all ethnicities falling under the umbrella of communism and more famously, a caricature of Vladimir Lenin sweeping kings, priests, and wealthy capitalists from the face of the earth. Nonetheless, communist leaders in Russia continued to embrace hegemonic traditions akin to those maintained during the colonial period.

Although the analysis of Russia's economic hegemony over Central Asia primarily relies on information derived from the Soviet and post-independence period, it is particularly important to observe the influential presence that Russia maintained in the region during the late part of the 19th century. In the beginning stages of Central Asian colonization, Russia's imperial government aimed to fulfill the goal of territorial expansion rather than exploitation of human labor. Furthermore, Russian colonization was synonymous with military prestige as nomadic Kazakh tribes sought protection from powerful Mongolian tribes. Thus, the initial unspoken code regarding Russian rule was that the powers of the imperial government "...were strictly limited: to maintain law and order at a minimum cost and to disturb as little as possible the traditional 
way of life of its new subjects" (Allworth, 1998). However, this would not be the case with the onset of early industrialization.

Perhaps the most significant feature of industrialization in Central Asia was the construction of railroads, which extended the Trans-Caspian Railroad to Samarkand in Southeastern Uzbekistan and Tashkent in the Northeastern region. Later on after WWI, these railroads would be further expanded into Turkestan-Siberian Railroad, intersecting various major cities in Kazakhstan and Uzbekistan. Economically speaking, these railroads, of course, were developed for the purpose of transporting raw materials from agrarian Central Asia to "big brother" Moscow and St. Petersburg. Another incentive for the construction of railroads was the establishment of what Edward Allworth refers to as "Garrison towns" or "European suburbs." These areas would become home to military troops and slowly paved the way for the incorporation of Russian language into newly founded educational institutions, efficient irrigation systems, and the oppression of the nomadic and clan-centric lifestyle of Kazakhs. Furthermore, countless scholars agree that while modernization and industrialization can generally be labeled as a positive development in the scope of 21 st-century Central Asia, the transformation of Kazakh lands into Russian-owned farms and military bases triggered famine among nomads who relied on natural water sources and grasslands for cattle grazing. As in many cases of colonial oppression, nomadic Kazakh tribes and native Kyrgyz peoples staged multiple bloody rebellions “...in which many colonists and many more Kazakhs and Kyrgyz were massacred" while another "...300,000 Kazakhs are said to have sought refuge across the Chinese frontier." (Allworth, 1998)

Following the Russian Revolution in 1917, which saw the Bolsheviks removing Russia's system of imperial hegemony, the Soviet Union was formed in 1922. However, most Central 
Asian nations were only annexed during the mid-1920s and 1930s. In particular, the Kazakh S.S.R. (now Kazakhstan) in 1936, the Kirgiz S.S.R. (now Kyrgyzstan) in 1936 and the Uzbek S.S.R. (now Uzbekistan) in 1924. With these annexations came the establishment of mono-product economies, a system created by the Gosplan agency (Gosplan being the state planning committee of the USSR) under the Stalin regime for the purpose of improving the Soviet Union's socio-economic landscape and promoting rapid industrialization. Under a mono-product economy, each republic of the USSR would become the primary producer of a one particular product such as “...machinery, raw material, and fuel...”(Myint, 1999) and thus, contribute to the interdependence of goods and services between Soviet nations that were not permitted to export domestically made products to nations outside of the USSR. Moreover, the Soviet Union's system of mono-product economies also resulted in the creation of 'monotowns' (borrowed from the Russian term, моногород), or cities that specialized in the production of one type of good, generally based in the industrial sector. This arrangement of mono-product economies primarily served the interests of Moscow, which syphoned resources from subordinate republics in exchange for foodstuffs and ultimately hampered the potential for flourishing in the post-Soviet period.

Additionally, it is significant to note that during the initial stages of the Soviet Union's formation, the "...Soviet government found itself the owner of all the means of production" and successfully undertook the task of "central economic planning" (Myint, 1999). In other words, the state, mainly based in Soviet Russia, gained complete control over industry and international trade, all private property was nationalized, and private enterprises were prohibited (Myint, 1999). The dissolution of private land ownership in Central Asia was notably impactful as, in contrast to industrializing republics like Ukraine and Belarus, Kazakhstan, Uzbekistan, and 
Kyrgyzstan were traditionally agrarian. Thus, "With priority given to industrialization, agriculture during the regime of Stalin was essentially treated as a source of cheap food and materials for the cities." (Myint, 1999) Of course, the revitalization of collective farming launched Central Asian farmers into yet another bout of famine as it proved to be an ineffective system for maintaining food security due to the lack of human incentive to plow the fields and harvest crops from nationalized land. Furthermore, and beyond the human consequences, Soviet economic planning also exhibited a disregard for the environment. This feature would later result in multiple ecological disasters, nuclear pollution, and the depletion of natural water resources from areas such as the Aral Sea.

The story of collectivization and the significance of agrarian economies during the Soviet Union can perhaps be best demonstrated through the case study of Uzbekistan. Located between Kazakhstan and Turkmenistan and retaining a portion of the Aral Sea, Uzbekistan has relied on cotton or 'white gold' as its main cash crop since before the solidification of imperial Russian power during the period of colonization. However, efficiency and accelerated rate of production was only brought about after the republic's annexation. More specifically, the Soviet government, through central planning and the establishment of mono-product economies, "imposed cotton as the major crop" and constructed an irrigation system in Uzbekistan (Abdullaev, 2009, pp. 47-48). This irrigation system would primarily rely on the Aral Sea. Furthermore, the rate of cotton production was further accelerated by the Soviet government's investment in “...machinery, fertilizers, pesticides and improved cotton varieties" (Reyes, 2015). However, as Cazzie Reyes notes in her article about the historical timeline of cotton production in Uzbekistan, investments from the Soviet government were strictly funneled towards “...increasing cotton fiber production rather than creating jobs and opportunities throughout the 
cotton value chain (e.g., textile production)". That is, retaining membership in the Soviet Union prevented agrarian Uzbekistan from industrializing and/or cultivating other crops.

Moreover, the Soviet government also imposed quotas on collective farms (kolkhozi) in Uzbekistan. Although data regarding specific daily quotas are unavailable for the period in which Stalin held power, reaching the daily minimum of harvested cotton was nonetheless a brutal task for agrarian nations that lacked the proper farming equipment. Unfortunately for Uzbek citizens, this translated into exploitation in the form of forced adult and child labor. According to a popular Soviet newspaper called 'Pravda', roughly two million school children consistently worked in Uzbekistan's cotton industry and were responsible for harvesting one-third of all the raw cotton in the nation (Gillette, 1985). Oftentimes, cotton harvesting was considered to be part of the public education curriculum in which students worked for little to no wage. Furthermore, in an anonymous letter written by parents of Uzbek child laborers, students endured “...primitive living conditions", which included crowding, contaminated drinking water, and the withholding of meals to students that were unable to meet their daily quotas (Gilette, 1985). The same was true for the adult exploitation, as discussed below.

The exploitation of human labor similarly extended to adults. For instance, rural regions in Uzbekistan were bound to Soviet-established tradition of picking cotton by hand. This was known as 'Kashgar' and required villagers of all ages to participate in seasonal cotton harvesting. Not only that but working professionals such as school teachers and doctors were also obligated to work in cotton fields without pay. The consequences of refusing to participate in the harvest generally consisted of exorbitant fines, potential imprisonment, harassment from employers, and job loss. Another instance of government injustice against Uzbek cotton growers was the amount of land allocated for growing food for independent households as compared to cotton for the 
USSR. In accordance with reports compiled by Robert Gilette, the Soviet government allocated $3 \%$ of cultivated land to produce $30 \%$ of locally-consumed “...meat, milk, eggs, fruit and vegetables. (Gillette, 1985)" In combination, all of these factors contributed to the fact that Uzbekistan produced $60 \%$ of all raw cotton in the Soviet Union.

\section{Uzbekistan's "White Gold"}

Though students today react in horror at history textbooks that portray mass starvation and human slavery within the astringent system of collectivization, modern-day Uzbekistan continues to reflect Soviet-style central planning. However, in order to fully illustrate the recent socio-economic climate of Uzbekistan, one must first analyze the developments that occurred during the transition period that followed the collapse of the USSR in 1991. Unlike Kazakhstan, Uzbekistan's government and newly elected president, Islam Karimov, rejected the concept of democracy and embraced authoritarianism---a decision that would translate into the continued tradition of forced human labor in the cotton industry, rising poverty rates, poor living conditions in rural areas, the preservation of outdated irrigation systems, and absence of land privatization. Furthermore, Uzbekistan's newly independent government was hesitant to follow the soon-to-be economically thriving Kazakhstan in pursuing a “...path of radical liberal reforms. (Pataccini \& Malikov, 2020, p.292)" By contrast, the nation implemented “... a gradual approach to the transition, sometimes referred to as the "Uzbek model...this strategy was characterized by one key objective_- "stability at any cost". (Pataccini \& Malikov, 2020, p.292)" While "stability at any cost" certainly calls for concern within the scope of human rights, scholars such as Sherzod Salimov argue that the Uzbek model was imperative for salvaging Uzbekistan's economy. In a brief statement, the condition of Uzbekistan's economy after the collapse could be characterized by a host of major problems such as: 
complete decline in manufacturing, non-provision of the production capacity with work, the growth of the unemployment rate, noncompliance of the monetary and fiscal political systems...The main economic indicators such as GDP, national income, and labor productivity had been steadily declined. Foreign trade turnover declined, negative balance of foreign trade and public debt increased and continuous inflation was irritating everybody. (Salimov, 2018, p.1) The Uzbek model of economic development contained many features akin to the Soviet concept of nationalized land, an outdated set of codes established as early as 1922. The basis of preserving Soviet-style centralization was founded on Karimov's statement of "Don't destroy the old house without building a new one. (Salimov, 2018, p.2)" Furthermore, the Uzbek model was established on principles that prioritized the international economy above domestic politics and asserted a gradual transition into a market economy. In promoting this model, Uzbekistan's government continued to uphold an unbalanced social order and consciously turned a blind eye to the grievances of ordinary citizens suffering from low standards of living and the highest rate of unemployment ever recorded in Uzbekistan's history (Salimov, 2018, p.2).

In application, the Uzbek model called for a minor degree of land privatization and caused impediments with regard to reforms in the agricultural sector. For instance, while Uzbek citizens technically received rights to land ownership in the form of 50-year leases, they were not permitted to sell, mortgage, or exchange private land (Djanibekov, 2010, p.4). Rather, households and small farmers were required to dedicate a portion of their land to growing cotton for the state---that of which the average local farmer received no compensation for. Of course, this also posed the problem of food insecurity among farmers who were forced to prioritize government mandated crops over foodstuffs. The penalty for refusing to grow cotton would, 
again, be costly fines and even land confiscation through the cancellation of leases (Djanibekov, 2010: p.4).

The transition from socialism also brought about an elite class or "new bourgeoisie" (Baykal, 2006) as Uzbekistan began its transition into a market economy. Alsi Baykal labels this class as 'Busheviks' due to their constant manipulation of the domestic economy. This includes the erratic impositions of trade restrictions and spontaneous closures of local businesses. Thus, despite the fact that so-called 'Busheviks' embrace Uzbekistan's new market-based economy, the group consistently demonstrates Soviet-style leadership tactics. What's more, many members of Uzbekistan's new elite class were previously considered as Communist Party elites during the Soviet period (Baykal, 2006). Subsequently, there exists widespread debate about how wealth and property were redistributed following the collapse. This question is further emphasized by the examination of Uzbekistan's increasing unemployment rates, poverty statistics, and the lack of state-funded financial assistance programs.

Another challenge that the agricultural sector in Uzbekistan faced after 1991 was maintaining the delicate balance between producing enough wheat for national food security and cotton for exportation. During the Soviet period, Uzbekistan was reliant on the barter system to feed its population. That is, Uzbekistan exported cotton to other republics of the USSR in exchange for wheat imports. However, this system inevitably dissolved with the introduction of the cash market to most of the former Soviet Union. Thus, Uzbekistan was forced to decrease the production of cotton and increase the output of wheat starting from 1996 (Abdullaev, 2009: p. 49). By 2004, Uzbekistan was producing 5.2 million tons of wheat each year, an increase of over 4 million tons since 1996. In sum, the rug of Soviet barter economies having been pulled out from beneath Uzbekistan resulted in the expansion of agricultural activities. Today, Uzbekistan 
produces roughly 7.6 million tons of wheat each year, a number that is predicted to continue to grow exponentially in the following years. Additionally, Uzbekistan has now emerged as the 8th largest exporter of wheat in the world, a positive development as the crop continues to raise the nation's GDP and allows Uzbekistan to expand its export of prepared foodstuffs such as bread.

However, while Uzbekistan has seen a massive growth of crop output within the agricultural sector, the threat of regional droughts looms over the cotton industry. This stems from the Soviet-made irrigation systems that have been funneling water from the Aral Sea to Uzbek cotton fields since the 1930s in an effort to boost cotton exports to Russian textile mills. At the time, environmental impacts were not taken into thoughtful consideration as Soviet agricultural planners:

"knew that increased withdrawals from the rivers would shrink the Aral Sea to a residual brine lake. However, they believed that when the benefits of increased agricultural output were weighed against the ecosystem service benefits of the sea, the Aral's desiccation was worthwhile." (Bennett, 2008) By the 1960s, the Aral Sea began experiencing significant water loss and reduced by more than $50 \%$ during the mid-2000s. Simultaneously, "cotton area in the UzSSR [Uzbekistan] increased by 23\%" from the 1960s (Djanibekov, 2010, p.2). Nonetheless, the government of Uzbekistan is still reported to be syphoning water from the sea due to fear that a large portion of the population would lose their livelihoods within the agricultural sector. However, the government has simultaneously sacrificed “... 60,000 jobs linked to the Aral Sea fishery...” (Bennett, 2008) and risks compromising the quality of Uzbek cotton due to increased salinity and pollution in the remaining volume of the Aral Sea. Beyond the potential foreshadowing of economic devastation 
within the sphere of agriculture, the disregard for ongoing environmental problems is reminiscent of the Soviet-inspired principle of progression and improvement at any cost.

Fortunately, however, the inhumane side of Uzbekistan's cotton industry has received global attention in recent years. Through the circulation of photos in which young children are hampered by large sacks of raw cotton and child labor surveys performed by the International Labor Organization (ILO), frequent buyers of Uzbek cotton are putting their feet down with boycotts. In fact, over 300 companies worldwide have signed the "Uzbek Cotton Pledge" which pressures unethical industries to end the use of child labor through the refusal to purchase cotton (Batmanghelidj \& Shaykhov, 2020). Some fashion giants within this pledge include Germany's Adidas, Spain's Zara, and America's Macy's. Moreover, the pressure of the Uzbek Cotton Pledge has weakened Uzbekistan's authoritarian grip as president Shavkat Mirziyoyev took power in 2016 following Karimov's 25-year rule and has influenced the government to purchase roughly 6,000 units of harvesting equipment to replace human labor (Batmanghelidj \& Shaykhov, 2020). When speaking about natural resources in Central Asia, most literature would immediately point out that Kazakhstan is a lively hub for oil and natural gas while Uzbekistan maintains regional hegemony over agricultural exports. However, this sentiment is backed by the fact that basins on Uzbek soil were not investigated during the Soviet period as a result of the USSR's system of mono-product economies. In a current partnership with Tethys Oil, a Swedish oil company, Uzbekistan has experienced great success in mining the Western part of the Aral Sea. In fact, the country was able to build up a reserve of 594 million barrels of crude oil in 2016 and was named to be one of the top three producers of natural gas in Central Asia in 2015 (U.S. Energy Information Administration, 2016). Subsequently, Uzbekistan was able to establish larger partnerships in the sphere of energy as it now supplies "...gas into the pipeline to China and is 
acting as a transit country bringing gas from the super-giant fields in Turkmenistan for both the European and Chinese markets." (World Finance, 2014)" Nonetheless, smaller-scale companies such as Tethys Oil are no match for Uzbekistan's neighboring oil giants.

Though Uzbekistan has maintained a relatively successful post-independence economy with regards to energy and agriculture, there still remains holes that are filled by the interference of wealthy and thoroughly industrialized Russia. This, first and foremost, takes the form of Russia being Uzbekistan's primary trading partner within the sphere of energy. According to Gallo, Russian oil companies such as Gazprom and LUKoil have invested as much as 6 billion dollars into Uzbek gas from 2010 to 2015 (Gallo, 2020). Most of these investments have gone towards "geological survey and opening of oil and gas fields projects as well as into the modernization of pipeline infrastructure. (Paramonov \& Strokov, 2008, p.8)” In particular, developing oil fields in the depleted sections of the Aral Sea, mining in unexplored areas such as the Ustyurt Plateau, and the construction of a gas pipeline that would extend through Turkmenistan and Uzbekistan. Not only that but Gazprom is also working with the Uzbek company, Uztransgaz, to improve the efficiency of gas transportation.

The seasonal migration of Uzbek citizens to mega-cities in Russia like Moscow can be considered as the bear's indirect involvement within Central Asian economies. Out of all the former republics of the Soviet Union, Russia inarguably maintains a superior economy in which migrants from Central Asia can earn an exponentially higher income than in their home countries. In fact, it is estimated that salaries can range from five to twenty times more for seasonal blue-collar workers (Laruelle, 2007: p.105). Furthermore, Russia is an attractive destination for migrant workers due to the fact that citizens from most former Soviet republics are not required to have a visa for employment. In addition, the historical imposition of Russian 
language in Soviet republics creates a wider range of job opportunities for Central Asian migrants. These are perhaps reasons enough for $70 \%$ of Uzbek migrant workers to choose Russia as their temporary destination. Nonetheless, seasonal migrant workers tend to fulfill unprestigious positions in low-paying construction and janitorial jobs (Laruelle, 2007: p.107).

In the context of the information that points to a seemingly thriving economy, the massive outpour of migrant Uzbek workers to Russia may appear unexpected. However, agrarian economies traditionally lack the component of stable incomes among rural populations. That is, off-seasons and low-yield years can spell financial hardship for approximately $44 \%$ of Uzbeks (Djanibekov, 2010). In fact, it has resulted in a national poverty rate of $11.4 \%$, a marker that is above the global poverty rate. Furthermore, the process of rural workers migrating to urban regions of Uzbekistan can oftentimes be more arduous than migrating to neighboring countries. This is caused by a Soviet-made system known as "propiska" which "...ties individuals to a particular location, forcing them to live and work in one area - often the location of their birth. (Bhutia, 2020)" In other words, rural Uzbek citizens lack the opportunity to work in higher-paying occupations or even gain a tertiary education because of government sanctions on internal relocation to major cities such as Tashkent. Contrastively, Kazakhstan maintains a higher level of internal freedom and has joined Russia in becoming a host for Central Asian labor migrants.

\section{Kazakhstan's "Black Gold"}

Located North of Uzbekistan, Kazakhstan is a former republic that was uniquely industrialized as compared to the rest of Soviet Central Asia. The country is known for being a mass producer of oil, home to the Cosmodrome Baikonur, and an area rich in precious metals such as uranium. Much of the industrialization that Kazakhstan experienced was the result of 
Stalin's 5-year plan. In the context of the war, Kazakhstan played a key role in supplying the military with coal, metals, and oil. However, while Kazakhstan can pride itself in being one of the nations that were instrumental for the USSR's victory in WWII and continues to enjoy the economic fruits of early industrialization, it is essential to recognize the transgressions that occurred against the Kazakh people during this period.

As previously mentioned, Kazakhstan has a history of enduring collectivization and being forced to forfeit traditions revolving around nomadic culture. This pattern of developments stemmed from the period of imperial Russian colonization and lasted well into Stalin's rule. Moreover, while several scholars have rightfully argued against the negative ramifications of cultural issues such as language change and the loss of an estimated 1.5 million Kazakh lives, it is important to concede the unpopular opinion that some features of Russian hegemony were beneficial for the success of Kazakhstan's economy after the collapse. However, in order to prove such a bold claim one must first look back to the period that occurred, as Stalin began to take power.

Following the initial stages of Soviet collectivization and "sedentarization of the nomads" (Pianciola, 2001, p.240), Kazakhstan is measured to have suffered the most negative effects out of all Central Asian states. In just one city, a census recorded that roughly 55,000 Kazakhs were starving in 1924 due to the confiscation of grain yields and livestock. Of course, this would lead to turmoil in which Kazakhs revolted against livestock confiscation, often preferring to kill their own livestock rather than to forfeit them to the state (Pianciola, 2001, p.238). By 1928, the amount of livestock decreased by $35 \%$ as Kazakhs were forced to exchange live animals for grain in non-grain producing districts (Pianciola, 2001, p.240). This number declined to $4.5 \%$ at the peak of WWII. As a result, non-grain producing districts with declining livestock numbers 
and mass migrations to non-Soviet countries like China and Afghanistan were further influenced to embrace industrialization.

Nonetheless, the grain industry was still maintained during the Stalin era and was further revitalized by Nikita Khrushchev's Virgin Lands campaign in 1954. This plan aimed to reduce Soviet-wide food shortages by developing Northern Kazakhstan's unplowed lands into wheat farms. By 1955, 30 million hectares of virgin Kazakh soil was converted into farmland, 425 state-owned farms were established on newly developed land, and output of wheat was increased by a staggering 65\% (Durgin, 2007, p.255). However, during the Perestroika period and well into the post-independence period in 1999, economic instability from lack of government funding and political turmoil resulted in a harsh drop in grain prices. This was also coupled with a decline in viable wheat farms which had "...reached an all-time low during the transition crisis of the 1990s. In 1999, it [grain] stood at roughly half the value of the 1950s. (Petrick et al., 2013, p.166)" However, during an economic upturn in 2001, Kazakhstan experienced a 40.7\% growth rate in wheat production and would continue to see a significant rise every few years. Today, Kazakhstan continues to utilize land cleared by the Soviet Virgin Lands campaign and is the tenth largest exporter of wheat in the world, generating a total grain production of 16.5 million tonnes from 2019 to 2020 (Lyddon, 2020).

Another domestic product critical to the economy of Kazakhstan is the radioactive metal, uranium, which is naturally abundant in Central Asia. Uranium production in Kazakhstan gained its start when the company "Vostokredmet" began mining operations in various parts of Central Asia (Khlopkov \& Chekina, 2014, p.18 ). This preceded the creation of the Soviet Union's nuclear weapons program in 1942, which aimed to develop an atomic bomb during WWII. During the early stages of uranium production, methods of mining and transportation were 
extremely underdeveloped. In fact, uranium ore was carried to processing facilities by mules. However, after the implementation of a highly-effective mining method known as "in-situ leaching" in the 1960s, Soviet mining operations experienced a rapid increase in uranium output (Khlopkov \& Chekina, 2014, p.20). By the 1980s, the Soviet Union became the largest producer of uranium in the world, with the majority of uranium being mined in Kazakhstan.

To the despair of the USSR, this success would be short-lived as in 1991, Russia lost ownership of six out of seven major Soviet mining centers. Not only that but Central Asia retained ownership of almost $80 \%$ of Soviet uranium mining assets (Khlopkov \& Chekina, 2014, p.20). Nonetheless, the sudden loss of multiple significant mining sites was not enough to cut Russia out of the Central Asian uranium game. In 2007, the president of Russia, Vladimir Putin, founded the state-owned nuclear power company, Rosatom, which would quickly become a father company to uranium producers in Kazakhstan, Australia, and the US. This international appearance was aided by Rosatom's substantial budget for investment and eagerness to improve processing centers, establish nuclear plants, and create better methods of uranium transportation. In 2013 alone, Rosatom's Kazakh-based companies produced approximately 4,629 million tonnes of uranium (Khlopkov \& Chekina, 2014, p.29). In addition, one joint Kazakh-Russian company known as Kazatomprom produced 23\% of the world's uranium in 2019. Furthermore, staggering figures for uranium output have continued to rise as Kazakhstan has been the world's top extractor of uranium for years, with other big players like Australia trailing far behind.

With regard to early industrialization and the significance of "black gold" in Central Asia, it can be said that Kazakhstan played an entirely different role than Uzbekistan in the Soviet Union. That is, Kazakhstan was “...based almost exclusively on oil and gas extraction... The central state, in turn, provided Kazakhstan with subsidies needed to feed its population." 
(Sairanen, 2019). However, a similarity lies in the fact that the two Central Asian republics were required to produce one specific product in exchange for food supplies. Furthermore, the Soviet period was not the first time Kazakhstan would dip its toes into oil production as the substance was mined on a minor scale in 1899 (Kanapiyanova, 2019, p.28). Not only that but various large oil basins such as the Makat and Dossor were being discovered in 1914. Until the establishment of the USSR, however, much of Kazakh oil was untouched and oil production was only developed to its peak in the 1960s when the Soviet government implemented "...higher speed turbine drilling...instead of rotary drilling. (Kanapiyanova, 2019, p.29)" This was one of the developments that greatly increased the oil output as turbine drills are more capable of drilling in harsh underground conditions within a shorter time span. In addition, Kazakhstan's rising oil industry was further aided by previously constructed railroads and Soviet-made pipelines that were connected to Russia.

The rapid expansion of the oil industry stands out as a byproduct of the Cold War, which reached its peak in the 1960s and 1970s. Particularly, before and during the oil crisis, a period in which the United states, despite containing few domestic points of oil drilling, produced two-thirds of the world's oil and stood as the largest producer of oil in the world (Painter, 2014, p.187). The Soviet Union almost constantly trailed far behind the US's rapid and efficient production rates. However, the US would later suffer as a result of its booming success due to inflation and a sharp increase in oil demand worldwide. Not only that but skyrocketing oil prices created the issue of access to the substance in developing countries, causing a temporary decline in overall demand. In contrast, the Soviet Union thrived in the midst of the oil crisis. This was largely due to the many oil-rich basins located in Central Asia and Siberia. By the mid-1960s and early 1970s, the Soviet Union had tripled its oil exports and began supplying oil to "...Cuba and 
Vietnam at subsidized prices, and sent oil as economic assistance to Afghanistan, Ethiopia, Mozambique, Nicaragua, and South Yemen. (Painter, 2014, p.194)" In addition, and perhaps most importantly, the Soviet Union also surpassed the United States within the sphere of oil production and continued to expand drilling operations in Central Asia in order to preserve this economic victory.

In accordance with wheat production, Kazakhstan's output of oil also experienced a drastic decline during the last years of the Perestroika period and throughout much of the post-independence period. Luckily, however, Kazakhstan would not experience such a negative economic impact as did Uzbekistan. The main reason: foreign oil investments. This occurred after "National companies such as, "Kazakhoil" and "Kaztransoil" were established" and "were given the opportunity to participate in energy projects on behalf of the Kazakhstan government. (Kanapiyanova, 2019, p.29)" The list of major foreign oil companies in Kazakhstan is exhaustive, ranging from the Turkish National Oil Company to the Romanian National Oil Company Petrom.

However, America's Chevron undoubtedly maintains predominant interest in Kazakh oil as the company holds stakes in the Tengiz and Karachaganak fields and "...holds a 50 percent interest in Tengizchevroil." (Chevron, 2020)" Due to Chevron's hefty investments in developing Kazakh oil fields and operations for mining the region's "black gold", the US has become one of the country's top foreign investors, contributing about $\$ 5.3$ billion in 2019. Moreover, in 2016, Chevron announced a project for increasing crude oil production in Kazakhstan. This project is estimated to cost $\$ 36.8$ billion. In addition to Chevron, the US-based company ExxonMobil also maintains a prominent presence in Kazakhstan's oil industry, holding a 25\% stake in the Tengiz oil field (Kanapiyanova, 2019, p.30). For Kazakhstan, the presence of Chevron has reaped an 
abundance of social and economic benefits. The most notable being the development of the Karachaganak field, which produced 28,000 barrels of oil per day in 2019 and Chevron's investment in public education and healthcare infrastructures (Chevron, 2020).

While Chevron has gone to great lengths to present itself as a Western savior in Kazakhstan, the company fails to mention the negative aspects of its presence within the region. Halil Sakal (2014, p.243), for instance, argues that the presence of oil giants in developing or recently developed regions contributes to corruption in the form of nepotism and the unequal distribution of national oil profits. Additionally, Chevron's efforts to expand oil drilling operations in Kazakhstan have exposed surrounding waterways to pollutants and contributed to the thick layer of smog that currently hovers above major cities like Almaty. Correspondingly, Chevron has received an outpour of criticism from the Kazakh citizens, who emphasize the importance of corporate responsibility programs. In nations such as India, similar programs have seen success in preserving national heritage, creating community development initiatives, and managing the environment (Buldybayeva, 2014, pp.237-238).

Regardless of Western involvement in Kazakhstan's oil sector, Russia continues to find itself near the epicenter of daily oil operations. Much of this presence has to do with the fact that Russia is one of the world's largest producers of oil (only third to the US and Saudi Arabia) and that Kazakhstan is landlocked, leaving the Central Asian nation to make the bulk of its partnerships with surrounding countries. As previously mentioned, Kazakhstan's economic downturn in the 1990s was largely the result of losing ties with previous Soviet economic partners. This would result in Kazakhstan turning not only to China for trading, but also to Russia, the very entity that influenced economic instability in Central Asia. However, the bear was quick to overstep recently broken boundaries as in the late 1990s, "Russia tried to dictate the 
terms of price along their own lines and volumes supplies of Kazakhstan's oil. (Nurgaliyeva, 2016, p.93)"

What's more, Western Kazakhstan was reliant on Russian pipelines and most of the country's domestic oil refineries were connected to Siberian oil fields. These physical connections within the oil and gas industry have spelled trouble for Kazakhstan over the years. In particular, through the Russian government's desire to "renegotiate the Caspian Pipeline Consortium (CPC) contract, whereby oil from Kazakhstan's giant Tengiz field is piped to the Black Sea by a consortium of western and Russian firms. (Marten, 2006)" Moreover, because Kazakhstan was struggling to reach the desired output for domestic crude oil, it became reliant on crude oil from Siberia, which is estimated to have made up $75 \%$ of crude oil within large refineries such as "Pavlodar" and "Atyrau" in Eastern Kazakhstan (Ipek, 2007, p.1181). This resulted in Kazakhstan maintaining ties with Russian oil and gas companies well into the 21 st century. However, American investments and involvement within Kazakhstan's oil sector still remain supreme as the United States currently has a larger budget allocated for foreign investments and more advanced oil technology.

Aside from investments from the West, Kazakhstan has also extended its energy sector to China in an effort to separate itself from a new cycle of Russian dominance. Most of Kazakhstan's economic partnerships with China are based in Beijing, which has made significant investments in Kazakhstan's oil and mineral industry and has controlled 24\% of the country's oil production since 2009 (Gallo, 2020, p.16). Additionally, China has drastically decreased Kazakhstan's dependence on Russia through the construction of the first pipeline that crossed between Western Kazakhstan and Xijiang, China, rather than through Siberia. This is known as the "Central Asia-China pipeline, which supplies China with half of its natural gas imports 
(Kassenova, 2017, pp.110-111)." In sum, the financial contributions of China, Russia, and the US within Kazakhstan's oil sector ultimately lifted the industry from a 10\% dip in GDP during the mid-1990s and contributed to an economic boom in the mid-2000s that saw oil-based products become $73 \%$ of Kazakhstan's exports.

Moreover, the main actors (China, Russia, and the US) within Kazakhstan's thriving oil industry have perhaps enjoyed more benefits than Kazakhstan itself. Certainly, the Central Asian nation's economy has flourished in the post-independence period as a result of ample foreign investments. However, many of the oil field shares held by the previously listed actors are listed at more than $50 \%$ and have contracts that are active for up to 55 years (Watkins, 2005). Indeed, large-scale investors, and for the purpose of this thesis, Russia, will maintain economic hegemony within Kazakhstan's oil sector for generations to come.

Lastly, in 2015, the presidents of Kazakhstan and China, Nursultan Nazarbayev and Xi Jinping, came to an agreement about linking Kazakhstan’s Bright Path economic policy and China's better-known Silk Road Economic belt. This plan was announced as a 5-year project and would place particular emphasis on improving infrastructure, industry, and transportation. By 2016, the two governments established a list of three detailed priorities in the scope of Eurasian territories. These included: “...building several transportation corridors: China, Kazakhstan, and West Asia; China, Kazakhstan, Russia, and Western Europe...increasing the share of high-tech products and coordination of certification policies" in order to improve trading efficiency, and creating “...joint ventures in Kazakhstan’s SEZ — the Khorgos-Eastern Gate in Almaty Oblast and the National Industrial Petrochemical Technopark in Atyrau Oblast - and cooperation on biotechnology, energy, engineering technology, automobiles, construction materials, and textiles. (Kassenova, 2017, p.112)” Moreover, while the Silk Road and Bright Path agreement was 
initially greeted with open arms by Kazakh citizens, public outcry emerged when it was found that Kazakhstan's government passed legislation that would allow Chinese agricultural companies to lease farming land for 25 years rather than for the previous maximum of only 10 (Kassenova, 2017, p.113). Thereby, allowing a new powerful entity “...to poison the soil or capture and colonize land. (Kassenova, 2017, p.113)" This concern regarding China's ecological footprint comes from viewing the negative impact of Soviet irrigation systems on the Aral Sea, the degradation of soil on agricultural lands, and the presence of nuclear waste in regions that were used for nuclear weapon testing.

Speaking about foreign investments, it is worth noting that a significant and unique portion of them in modern Kazakhstan are derived from the physical remnants of the space race, a series of events that took place during the Cold War between the Soviet Union and United States. More specifically, the funds that the Kazakh government receives from renting out the famous Cosmodrome Baikonur---the station that launched the first man, Yuri Gagarin, and a variety of animal subjects into outer space. Cosmodrome Baikonur was constructed in 1955 in Southern Kazakhstan. During the Soviet period, the city was known as Leninsk or "Zvedograd". Operations in Baikonur were at their peak in the 1980s as the station was complete with ten on-site factories, fifty launch pads, a man-made lake, the best hospital in the USSR, and more. However, following the collapse, a decline in funding resulted in the majority of Baikonur's facilities to deteriorate into rusted skeletons of the original structures.

In spite of being virtually abandoned for almost five years, Russia enacted the gradual revitalization of Baikonur in 1996. This entailed allocating 296 billion rubles (roughly $\$ 4$ billion) to improving the station's infrastructure and placing Russian economic regulations upon the city of Baikonur. The area continues to operate under the same regulations today. Moreover, with 
Russian economic frameworks in place, the late 1990s saw a boom of local businesses and tourism as bazars, electronic stores, restaurants, museums, and hotels emerged. In addition, the space station has been commonly used by America's NASA, the European Space Agency, and Russia's Roscosmos. Russia alone pays an annual renting fee of $\$ 115$ million per year to Kazakhstan's government in order to continue operations in what is currently dubbed as the best space station in the world. Certain former republics such as Kyrgyzstan, however, have not been as fortunate in maintaining multiple successful streams of national profit.

\section{Kyrgyzstan's Mixed Economy}

Despite the fact that an overwhelming majority of Soviet republics operated under a mono-product economy, Kyrgyzstan has historically been a producer of various goods ranging from agricultural products to metals. In a sense, the nation is an amalgamation of Uzbek and Kazakh economic activities, even experiencing the same effects of colonization and annexation with regards to de-nomadization, industrialization, collectivization, and the introduction of formal Russian education. However, contrary to the assumption that Kyrgyzstan's economy would thrive after the collapse due to its variation in economic activities, the country has never quite recovered from the collapse of the USSR. Moreover, following the global financial crisis in 2008 , roughly $38 \%$ of the population was living beneath the national poverty line, most of which was located in agricultural regions (International Monetary Fund, 2014, p.1). However, before providing a further analysis of the state of Kyrgyzstan's current economic affairs, another glimpse into the Soviet period is required.

In 1928, shortly after the solidification of Soviet power in Central Asia, collectivization and "dekulakization (the dispossession and deportation of purportedly rich, exploiting peasants)" (Loring, 2008, p.183) resulted in multiple peasant rebellions. This, of course, is one of the many 
links in the pattern of collectivization-era rebellions. However, it can be said that the implementation of collectivization was simply the tipping point for Kyrgyzstan as the Soviet government had imposed a series of oppressive and disadvantageous reforms in the years prior. Furthermore, in addition to the acquisition of grain under collectivization, Kyrgyzstan also experienced "cottenization" at the same time as Uzbekistan (Loring, 2008, p.186). That is, the central Asian republics became powerhouses for raw cotton as the Soviet government aimed to become less dependent on capitalist states for certain imports. As a result, Central Asia was producing $75 \%$ of the entire Soviet Union's cotton by the end of the 1920s. Nonetheless, economic planners were determined to further increase cotton yield in increasing the price of cotton per unit and drastically decreasing the price of grain. Thus, providing incentive for farmers to grow cotton rather than an essential food product.

Another issue that emerged from collectivization and "cottenization" were land reforms carried out by the USSR's cotton committee, which took on the role of controlling land ownership and usage after the government confiscated the property of religious institutions and the bourgeois class (Loring, 2008: p.187). In particular, because the USSR's peasant class relied on a system of credit (credit received from growing crops for the state and exchanging it for foodstuffs and other items necessary for living), the Cotton Committee would routinely manipulate the allocation of credit based on changing quotas (Loring, 2008, p.187). In addition, the state “...enforced its priorities by offering advances of money, seed, water, or equipment in exchange for contractual obligations to deliver specified amounts of cotton. (Loring, 2008, p.190)" Unsurprisingly, the Cotton Committee's strategy would bring about a massive wave of food insecurity. 
In addition to the high rates of starvation that historically occur within systems of collectivization, it was also found that certain regions of the republic experienced weather unsuitable for growing cotton. Thus, the Western edge of Kyrgyzstan's territory was converted into farmland dedicated to growing grain. This decision would contribute to reducing starvation rates as the crop was collected from Western Kyrgyzstan and equally distributed among cotton districts. Not only that but the Gosplan committee also decreed that private trading in the grain sector or the existence of "chastniki" (coming from the root of the Russian word for "hourly"” would be reduced (Loring, 2008, p.194). Subsequently, private traders were forced to sell grain to the state at markedly low prices. By 1928, collectivization methods and unmet quotas set by the Gosplan's 5-year plan triggered a widespread famine and the dissolution of virtually all remaining "kulak" farms, repeating the pattern of being sold at low prices. In the years building up to the Soviet Union's involvement in WWII, 90\% of the republic's independent farms were transformed into state-owned collectivist farms.

During WWII Kyrgyzstan experienced an enormous shift as it rapidly moved from being chiefly agriculturally-based to a partially industrialized country. The unique reasons being that the republic was geographically isolated and too far for Nazi Germany's troops to reach (Prentice, 2020). During this industrialization period, "Dozens of key factories and military-related industrial plants were moved to the Kyrgyz cities of Bishkek...and Tokmak after being evacuated from regions threatened by the advancing Germans. (Prentice, 2020)" By the height of the Soviet Union's participation in WWII, Kyrgyzstan had become a mass-producer of metals. Many of the newly-built factories were sustained only by the labor of Kyrgyz women, as a large percentage of Kyrgyz males were drafted into the war. 
Although factories were initially constructed in Kyrgyzstan with the goal of temporarily producing wartime materials for Soviet troops, Kyrgyzstan would continue to play the role of a semi-industrialized republic until the collapse in 1991. In fact, the capital of independent Kyrgyzstan, Bishkek, is still known as being a large producer of machine parts and finished metals (Prentice, 2020). Aside from agricultural products, some of its major current-day exports include, gold (making up a staggering $50.5 \%$ of exports), copper, miscellaneous metal ores, and vehicle parts (Theklan, 2018).

Although the Soviet government played a negligible role in the actual development of Kyrgyzstan's largest gold mine, Kumtor, it was responsible for signing off on a geological expedition of North-Eastern Kyrgyzstan and an official report of the abundance of gold found in the area. However, when this occurred in the late 1970s and 1980s, the USSR was not able to allocate funds to the development of the mines. Shortly thereafter in 1992, the newly independent government of Kyrgyzstan was ready to receive foreign investments and signed an agreement for the commencement of the Kumtor gold project. Specifically, with the Canadian gold and uranium company, Centerra Gold, which currently retains complete ownership of the mine. In addition to developing the Kumtor mine, a location crucial to sustaining Kyrgyzstan's economy, Centerra Gold's operations make up 10\% of the nation's GDP, employ the highest number of Kyrgyz citizens, and has claimed to have invested \$27 million into the country’s agricultural sector and local businesses (Chen, 2020). However, recent protests for the nationalization of Kumtor have shaken Centerra Gold, as Kygyz citizens claim that the company has replaced the former Soviet government as a hegemonic force. As a result, the future of Centerra Gold's partnership with Kyrgyzstan remains uncertain. 
Moreover, on the topic of Kyrgyzstan's surviving industries from the Soviet period, Kyrgyzstan's top exports are industrial products (miscellaneous machine and car parts) at 67\% while the agricultural sector produces about $17 \%$, most of which come from the cotton industry that was established during the Soviet collectivization era. As of 2018, the country had only achieved a GDP of $\$ 8.09$ billion as compared to Kazakhstan's $\$ 179.3$ billion and Uzbekistan's \$50.39 billion (Theklan, 2018). In simpler terms, this statistic tells the story of an unstable and underdeveloped economy. Evidence for this claim is further demonstrated by the fact that one-fifth of Kyrgyzstan's population migrates to Russia for seasonal work as a result of labor market pitfalls. As of 2019, income generated by migrant workers in Russia accounted for more than $25 \%$ of Kyrgyzstan's GDP. Effectively, one of Kyrgyzstan's top exports can unofficially be considered human labor. Once again, Kyrgyzstan's reliance on blue-collar jobs in major Russian cities is an indicator of post-Soviet Russian economic hegemony.

Between 2015 and 2014, after Kyrgyzstan gained membership in the Russian-led Eurasian Economic Union (EEU), the country became all the more reliant on low-paying jobs in Russia to stimulate its economy. During this period, Russia experienced an influx of migrant workers from Uzbekistan and Kyrgyzstan due to relaxed migration regulations created by Russia for EEU members and observers. It is estimated that over 500,000 Kyrgyz citizens temporarily migrated to Russian megacities in 2015 (Sagynbekova, 2017, p.5). Following the increase of Kygyz migrants to Russia in 2015 and despite an economic crisis that same year, Kyrgyzstan also became "...the world's second most remittance dependent economy" as " $80 \%$ of Kyrgyz migrant workers send remittances to their families in Kyrgyzstan" at a rate of roughly $\$ 200$ per month (Sagynbekova, 2017, p.6). 
Interestingly, 36\% of Kyrgyz labor migrants are reported to be holders of advanced degrees, prompting the question of whether or not Kyrgyzstan's government plans to turn more of its efforts towards reducing domestic unemployment, which is cited as the second most common reason for migration after low wages (Sagynbekova, 2017, p.12). However, the nation seems to be following in the footsteps of Uzbekistan in encouraging migration and even setting up educational centers specializing in teaching Central Asian citizens Russian language, basic laws, and history (Сытых, 2021). In addition to this, programs have been put in place to offer prospective migrants free transport to Russia and meal tickets. Contrary to former republics such as Tajikistan, which is currently working to halt migration out of the country, it appears that Central Asian nations with underdeveloped economies will continue to take advantage of Russia's infinite opportunities for low-wage labor positions.

Moreover, Russia's economic grip continues to take hold of Kyrgyzstan in a multitude of other ways. In fact, out of the three Central Asian states mentioned in this thesis, Kyrgyzstan has encountered the bulk of Russian hegemony. In addition to lacking the economic development of Kazakhstan and Uzbekistan in the years following the collapse, one of Kyrgyzstan's pitfalls is its geographic location---the very feature that made the state significant to the Soviet government during WWII. In other words, Kyrgyzstan lacks the ability to establish trading networks due to the fact that it is landlocked between previous Soviet republics (Kazakhstan, Uzbekistan, Tajikistan) and China. Moreover, because Uzbekistan and Tajikistan are relatively poor countries, Kyrgyzstan's potential for trading partners is further decreased. This fact provides the most logical explanation for why Kyrgyzstan's major trading partners (with the exception of the $\$ 1.32$ billion worth of exports in gold and other metals being sent to the UK) are Russia and Kazakhstan (Theklan, 2018). 
In January of 2014, Russia further solidified its role in Kyrgyzstan's economy as multiple previous republics of the USSR signed a treaty to create the Eurasian Economic Union (EEU). Later that year in October, Kyrgyzstan also became a member. Currently, there are five active members---Belarus, Russia, Kazakhstan, Kyrgyzstan, and Armenia, and three observers---Cuba, Uzbekistan, and Moldova. According to Mostafa and Mahmood, one of Russia's main goals in signing the EEU treaty was to counterbalance "... the EU in the West and China in the East" as it sought to "limit and restrict Chinese economic influence and penetration in Central Asian markets" (2018, p.163). In the context of Kyrgyzstan and Russia, this meant that 'the bear' (Russia) could now assert more economic influence than 'the dragon' (China), which was rapidly gaining control of energy and mining branches in underdeveloped countries. As a whole, however, the EEU's main purpose is and was to promote the "...free movement of goods, services, capital and labor (Eurasian Economic Union, 2020)" and establish "several common markets, along with the "agreed and coordinated" policies between its member states. (Vicari, 2016, p.1)"

With regard to Kyrgyzstan's membership in the EEU, Mostafa and Mahmood argue that the country had two motifs for joining the union. Firstly, the presence of an axis power such as Russia in the EEU provided Kyrgyzstan with national security protection. This was a particularly significant perk for the nation as Islamic Fundamentalist terrorism threatens the region internally and externally (2018, p.166). Secondly, Kyrgyzstan sought to establish firm trading partners in light of being one of the poorest and socio-economically unstable nations in Central Asia (2018: p.166). In sum, EEU membership resulted in favorable outcomes for Kyrgyzstan, with some scholars even suggesting that it triggered an economic boom by 2015. Unsurprisingly, these positive changes largely came about from Russian investments. 
The bulk of positive changes as a result of EEU membership can be divided into four concrete developments. The first being that the state-owned gas company, Gazprom, “ ...assured oil and gas at a discounted price from Russia (Mostafa \& Mahmood, 2018, p.166)" in addition to promising investments towards improving Kyrgyzstan's gas facilities and pipelines. Not only that but Russia is said to have forgiven \$1 billion worth of Kyrgyzstan's national debt, continues to work on improving gas transportation networks that intersect Kyrgyz soil, and has created a joint Russian-Kyrgyz gas importation venture known as ‘KyrgyzgazProm' or 'Gazprom Kyrgyzstan' (Ott, 2014). However, this series of collaborations has been the subject of scrutiny as critics speculate that Russia's investments and discount oil deal with Kyrgyzstan were the result of EU sanctions placed upon Gazprom and Rosneft. This occurred as Russia invaded Crimea, Ukraine in early 2014.

Beyond providing defense against radical Islamic fundamentalism, Russia has also provided $\$ 500$ million to unknown Kyrgyz economic sectors in exchange for the closure of the American Air Force base, Manas (Ott, 2014). Prior to Kyrgyzstan's membership in the EEU, Russia was already asserting pressure for the removal of the base, agreeing "to write off almost $\$ 500 \mathrm{~m}$ of Kyrgyz debt in exchange for a 15 -year extension of the lease for a Russian military air base. (Ott, 2014)" Furthermore, Russia forgave another $\$ 500$ million worth of debt in exchange for a 15-year military contract that would allow the bear's troops to maintain a physical presence in the region. Lastly, the Russian government promised to give Kyrgyzstan's military \$1.1 billion worth of military equipment.

The third benefit of Kyrgyzstan's EEU membership can be traced back to the previously mentioned fact that seasonal migration of Kyrgyz citizens to cities like Moscow makes up more than 25\% of Kyrgyzstan's GDP. According to Mostafa and Mahmood (2018, p.166), establishing 
stronger ties with Moscow has the potential to increase remittance flow, which is reported to have increased by a small percentage from 2014 to 2017 ---about $3 \%$. This indicator is likely to continue growing as Russia continues to invest resources into various sectors of the Kyrgyz economy. Lastly, EEU membership is predicted to generate a higher rate of exports from Kyrgyzstan's agricultural sector. In particular, fresh produce, flowers, wheat, dried fruits, and nuts. It is suggested that export of these products will increase due to the lack of trade barriers within the EEU. Evidently, these points present the favorable side of Russian hegemony.

Nonetheless, Russian domination over Kyrgyz economy poses a threat that perhaps outweighs the rewards of the arrangement. According to Amorith Tan (2020), Moscow's strategy of offering EEU membership and loosening regional migration policies is rooted in the goal of creating a new economic bloc composed of former Soviet States. At the moment, Russia's focus is on Central Asia due to underdeveloped economies and established an extremely conspicuous presence in 2014, in the midst of the Crimean conflict and later annexation. Simultaneously, Russia established a physical presence in Kyrgyzstan through calling for the removal of an American Air Force base and the placement of Russian troops on Kygyz soil. In doing so, Russia not only asserted military dominance in the region, but also blocked the potential for future economic partnerships with the West.

\section{Conclusions}

As can be observed in the case-by-case examination of Uzbekistan, Kazakhstan, and Kyrgyzstan, the nature of Russia's direct and indirect involvement within the economies of Central Asia has stimulated a unique post-independence period, which starkly contrasts those of previously colonized nations such as India. Although annexation into the Soviet Union cannot be purely branded as colonialism, the pattern of events such as collectivization and human 
exploitation is comparable with regard to the concept of traditional hegemony. Additionally, former republics have also endured a loss of cultural identity as the Soviet period asserted russification and the notion that all citizens, despite their rich backgrounds, were simply soviets, rather than Kazakh, Uzbek, Kyrgyz, and so on. As a social consequence, populations raised during the USSR's active years primarily spoke Russian---most would hardly reach fluency in the native tongue of their country. At the same time, however, the poisoning of local languages also unlocked an unforeseen potential for independent nations of the former USSR to restructure previous trading networks. Nonetheless, Central Asian nations (most notably, Kazakhstan) aim to reassert previously rejected languages through the means of public education and pride themselves on their ties to ancient nomadic tribes.

With regard to economic ruptures during the transition period, it can be noted that one of the most significant pitfalls that Kazakhstan, Kyrgyzstan, and Uzbekistan faced was a sharp drop in export rates and correspondingly, significant fluctuations in GDP. In order to reassert domestic stability, the three landlocked nations were forced to create new chains of interdependence through accepting investments and project proposals from large foreign corporations that have since asserted dominance over areas rich in uranium, gold, and oil. In addition to this, the three former republics have also developed a reliance on China, which has pooled $82 \%$ (or $\$ 21$ billion) of its national investments into Kazakhstan's hydrocarbon sector (Batsaikhan \& Dabrowski, 2017, pp.304-305). On a smaller scale, Russia has also emerged as a major investor in Central Asia's energy sector as it contributed roughly $\$ 12.7$ billion to various regional energy projects in 2015 (Batsaikhan \& Dabrowski, 2017, pp.304-305). As a result, Kazakhstan, Kyrgyzstan, and Uzbekistan have become arenas in which international corporations and world superpowers battle to create new chapters of hegemony over post-Soviet Central Asia. In the context of 
Russian and Chinese involvement, various unions such as the EEU and Shanghai Cooperation Organization are currently making a direct effort to absorb Central Asia into a new economic bloc, comparable to the network of interdependent states established by the USSR.

Throughout the process of annexation and the eventual collapse of the Soviet Union, newly independent nations faced, and continue to face, various socioeconomic and political factors that contribute to a rollercoaster of both pitfalls and opportunities for economic development. These developments are most often centered around the prospect of foreign investments, formation of various economic unions, regional migration, and changes in industries pioneered by Soviet economic planning. Furthermore, though the statistical projections presented by scholarly sources provide an astute glance into the economic affairs of Central Asia, it is crucial for researchers to also acknowledge the human aspect of a prolonged history of Russian hegemony over the region. My hope is that this goal was attained in this case-by-case thesis as numerical figures were presented alongside the experiences and perspectives of Kazakh, Uzbek, and Kyrgyz citizens. 


\section{Addendum}

Central Asia (Atkinson, 2016)

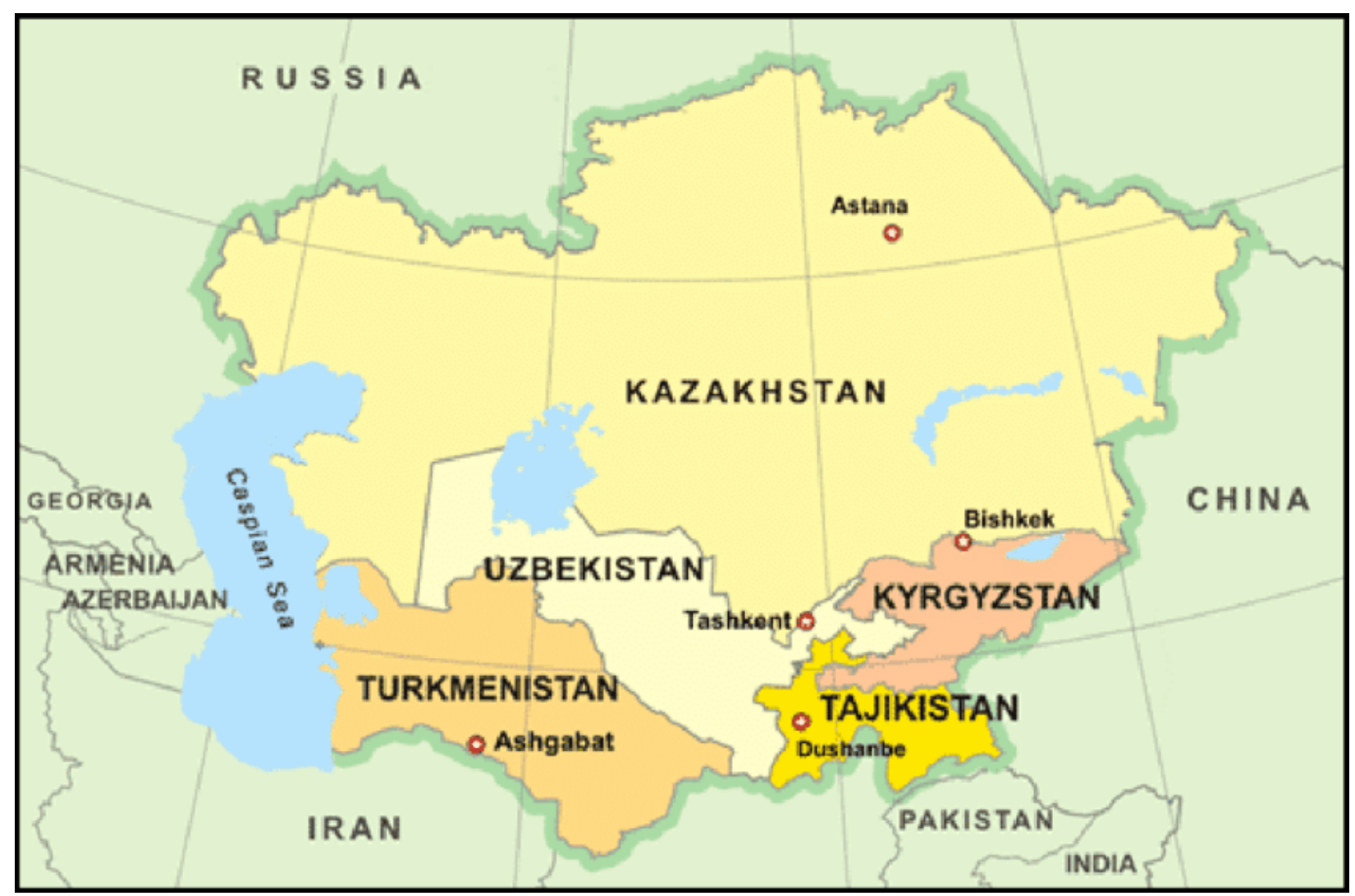


Work Cited

Abdullaev, I. (2009). Agricultural Water Use and Trade in Uzbekistan: Situation and Potential Impacts of Market Liberalization. International Journal of Water Resources Development,

25(1), 47-63. https://doi.org/10.1080/07900620802517533

Allworth, E.(1998, October 19). History of Central Asia - Soviet rule. Encyclopedia Britannica. https://www.britannica.com/topic/history-of-Central-Asia/Soviet-rule

Atkinson, B. (2016, April). Map of Central Asia [Map]. Research Gate.

https://www.researchgate.net/figure/Map-of-Central-Asia-downloaded-from-http-wwwsai $\underline{\text { ramtourismcom-ca-today-on fig8 } 308522990}$

Batmanghelidj, E., \& Shaykhov, O. (2020, March 28). The Boycott on Uzbek Cotton Needs to End. Foreign Policy. https://foreignpolicy.com/2020/03/28/international-cotton-boycott-uzbekistan/

Batsaikhan, U., \& Dabrowski, M. (2017). Central Asia — twenty-five years after the breakup of the USSR. Russian Journal of Economics, 3(3), 296-320. https://doi.org/10.1016/i.ruje.2017.09.005

Baykal, A. (2006). From Bolsheviks to Busheviks: The Uzbek Political Elite. Institute for Human Sciences. https://www.iwm.at/publications/5-junior-visiting-fellows-conferences/vol-xix/asli-bavka $\underline{1}$ 
Bennett, K. (2008, May 23). Disappearance of the Aral Sea. World Resources Institute.

Retrieved December 23, 2020, from https://www.wri.org/blog/2008/05/disappearance-aral-sea\#:\%7E:text=In\%201918\%2C\% 20policymakers $\% 20$ from $\% 20$ the, the $\% 20$ Amu $\% 20$ Darya $\% 20$ for $\% 20$ irrigation.\&text=But \%20with\%20its\%20major\%20inflows,began\%20shrinking\%20in\%20the \%201960s.

Bhutia, S. (2020, January 15). Uzbekistan sustains poverty by blocking internal migration.

Eurasianet. https://eurasianet.org/uzbekistan-sustains-poverty-by-blocking-internal-migration

Blakemore, E. (2020, September 2). How the Red Terror set a macabre course for the Soviet Union. National Geographic. https://www.nationalgeographic.com/history/article/red-terror-set-macabre-course-soviet$\underline{\text { union }}$

Buldybayeva, G. (2014). Both Sides of CSR Practice: A Case from Oil and Gas Industry in Kazakhstan. Acta Polytechnica Hungarica, 11(02), 229-248. https://doi.org/10.12700/aph.11.02.2014.02.14

Central Asia: a major player in the oil and gas energy industry. (2014, January 16). World

Finance.

https://www.worldfinance.com/markets/central-asia-a-major-player-in-the-oil-and-gas-en $\underline{\text { ergy-industry }}$ 
Chen, J. (2020, October 9). Kyrgyzstan Political Turmoil and Mining Jurisdiction Risks.

\section{MINING.COM.}

https://www.mining.com/kyrgyzstan-political-turmoil-and-mining-jurisdiction-risks/

Chevron. (2020). Kazakhstan Highlights of Operations.

https://www.chevron.com/worldwide/kazakhstan\#:\%7E:text=Chevron $\% 20 \mathrm{is} \% 20 \mathrm{Kazakhs}$ tan's $\% 20$ largest $\% 20$ private, developing $\% 20$ the $\% 20$ nearby $\% 20$ Korolev $\% 20$ Field.

Djanibekov, N., Rudenko, I., Lamers, J., \& Bobojonov, I. (2010). Pros and Cons of Cotton

Production in Uzbekistan (No. 7-9). Cornell University Library. https://ecommons.cornell.edu/handle/1813/55707

Durgin, F. (2007). The Virgin lands programme 1954-1960. Europe-Asia Studies, 13(3), 255-280. https://doi.org/10.1080/09668136208410287

Eurasian Economic Union. (2020). Eurasian Economic Union: General Information. http://www.eaeunion.org/?lang=en\#about

Gallo, E. (2020). Globalisation, Authoritarianism and the Post-Soviet State in Kazakhstan and Uzbekistan. Europe-Asia Studies, 73(2), 340-363. https://doi.org/10.1080/09668136.2020.1761297

Gillette, R. (1985). Some 12 or Younger : Soviet Cotton Harvest: Job for Children. Los Angeles Times. https://www.latimes.com/archives/la-xpm-1985-10-09-mn-16743-story.htm 
International Monetary Fund. (2014, August). The Kyrgyz Republic: Poverty Reduction Strategy Paper (No. 247). https://www.imf.org/external/pubs/ft/scr/2014/cr14247.pdf

Ipek, P. (2007). The role of oil and gas in Kazakhstan's foreign policy: Looking east or west? Europe-Asia Studies, 59(7), 1179-1199. https://doi.org/10.1080/09668130701607144

Kanapiyanova, Z. (2019). History of the Energy Sector Development and Kazakhstan's Energy Potential. Eurasian Research Journal, 1(2), 25-38. https://dergipark.org.tr/en/pub/erj/issue/47886/605473

Kassenova, N. (2017). China's Silk Road and Kazakhstan's Bright Path: Linking Dreams of Prosperity. Asia Policy, 24(1), 110-116. https://doi.org/10.1353/asp.2017.0028

Khlopkov, A., \& Chekina, V. (2014a). Governing Uranium in Russia. Econstor, 2014(19), 1-67. https://www.econstor.eu/bitstream/10419/120406/1/818453915.pdf

Laruelle, M. (2007). Central Asian labor Migrants in Russia: The "Diasporization" of Central Asian states? Semantic Scholar, 5(3), 1-19. https://www.semanticscholar.org/paper/Central-Asian-Labor-Migrants-in-Russia\%3A-Th e-of-the-Laruelle/2968a4e73dacd0f5eedc08210f37a7faaf63eac7\#citing-papers

Loring, B. (2008). Rural Dynamics and Peasant Resistance in Southern Kyrgyzstan, 1929-1930. Open Edition Journals, 49(49/1), 183-210. https://doi.org/10.4000/monderusse.9124 
Lyddon, C. (2020, June 18). Focus on Kazakhstan. World Grain.

https://www.world-grain.com/articles/13838-focus-on-kazakhstan\#:\%7E:text=Kazakhsta n $\% 20$ has $\% 20$ become $\% 20$ an $\% 20$ important, two $\% 20$ neighbors $\% 2 \mathrm{C} \% 20$ Afghanistan $\% 20 \mathrm{a}$ nd $\% 20$ Uzbekistan.\&text=About $\% 2012.9 \% 20$ million $\% 20$ tonnes $\% 20$ of, $3.8 \% 20$ million $\% 2$ $\underline{0 \text { in } \% 202019 \% 2 \mathrm{D} 20 .}$.

Marten, K. (2006). Disrupting the Balance: Russian Efforts to Control Kazakhstan's Oil.

PONARS Eurasia.

https://www.ponarseurasia.org/memo/disrupting-balance-russian-efforts-control-kazakhst $\underline{\text { ans-oil }}$

Mostafa, G., \& Mahmood, M. (2018). Eurasian Economic Union: Evolution, challenges and possible future directions. Journal of Eurasian Studies, 9(2), 163-172. https://doi.org/10.1016/j.euras.2018.05.001

Myint, H. (1999, July 26). Economic Planning. Encyclopedia Britannica. https://www.britannica.com/topic/economic-planning

Nurgaliyeva, L. (2016). Kazakhstan's economic soft balancing policy vis-à-vis Russia: From the Eurasian Union to the economic cooperation with Turkey. Journal of Eurasian Studies, 7(1), 92-105. https://doi.org/10.1016/i.euras.2015.10.008

Ott, S. (2014, September 18). Russia tightens control over Kyrgyzstan. The Guardian. https://www.theguardian.com/world/2014/sep/18/russia-tightens-control-over-kyrgyzstan 
Painter, D. (2014). Oil and Geopolitics: The Oil Crises of the 1970s and the Cold War. Historical Social Research / Historische Sozialforschung, $39(4$ (150)), 186-208. Retrieved February 21, 2021, from http://www.jstor.org/stable/24145533

Paramonov, V., \& Strokov, A. (2008). Russian Oil and Gas: Projects and Investments in Central Asia. Advanced Research and Assessment Group, 8(19), 1-25. https://www.files.ethz.ch/isn/92629/08 May_2.pdf

Pataccini, L., \& Malikov, N. (2020a). Transition and Regional Cooperation in Central Asia: What Can They Tell Us about the(Post-)Liberal World Order? The University of Chicago Press Journals, 52(2), 288-303. https://doi.org/10.1086/708184

Petrick, M., Wandel, J., \& Karsten, K. (2013). Rediscovering the Virgin Lands: Agricultural Investment and Rural Livelihoods in a Eurasian Frontier Area. World Development, 43, 164-179. https://doi.org/10.1016/j.worlddev.2012.09.015

Pianociola, N. (2001). The Collectivization Famine in Kazakhstan, 1931-1933. Harvard Ukrainian Studies, 25(3/4), 237-251. Retrieved January 24, 2021, from http://www.jstor.org/stable/41036834

Prentice, D. (2020, May 8). Kyrgyzstan's Forgotten Role in World War II. The Diplomat. https:/thediplomat.com/2020/05/kyrgyzstans-forgotten-role-in-world-war-ii/ 
Reyes, C. (2015, October 19). History of State-Imposed Forced Labor in Uzbekistan's Cotton

Industry. National Underground Railroad Freedom Center.

https://www.endslaverynow.org/blog/articles/history-of-state-imposed-forced-labor-in-uz $\underline{\text { bekistans-cotton-industry }}$

Sagynbekova, L. (2017). International Labour Migration in the Context of the Eurasian

Economic Union: Issues and Challenges of Kyrgyz Migrants in Russia. University of Central Asia, 39(2017), 1-29. https://doi.org/10.2139/ssrn.3023259

Sairanen, M. (2019, April 23). Soviet Legacies and the Consolidation of Economic Rentierism in Kazakhstan. E-International Relations.

https://www.e-ir.info/2019/04/22/soviet-legacies-and-the-consolidation-of-economic-renti erism-in-kazakhstan/

Sakal, H. (2014). Natural resource policies and standard of living in Kazakhstan. Central Asian Survey, 34(2), 237-254. https://doi.org/10.1080/02634937.2014.987970

Salimov, S. (2018). Some Aspects of the Principles of the "Uzbek Model” of Economic Progress.

Arts and Social Sciences Journal, 09(06), 1-3. https://doi.org/10.4172/2151-6200.1000426 
Tan, A. (2020, January 30). China and Russia: Competition in Kyrgyzstan. Future Directions

International.

https://www.futuredirections.org.au/publication/china-and-russia-competition-in-kyrgyzst

$\underline{\mathrm{an} /}$

Theklan. (2018). Kyrgyzstan (KGZ) Exports, Imports, and Trade Partners. The Observatory of Economic Complexity. https://oec.world/en/profile/country/kgz

Uzbekistan. (2016, July). U.S. Energy Information Administration.

https://www.eia.gov/international/analysis/country/UZB

Vicari, M. (2016). The Eurasian Economic Union- Approaching the Economic Integration in the Post-Soviet Space by EU-Emulated Elements. Open Edition Journals, 55(2016), 1-16. https://doi.org/10.4000/interventionseconomiques.2823

Watkins, E. (2005, July 8). Russia, Kazakhstan Sign Kurmangazy Field PSA. Oil \& Gas Journal. https://www.ogj.com/exploration-development/article/17244163/russia-kazakhstan-sign-k urmangazy-field-psa

Сытых, И. (2021, January 8). «Трудовая миграџия - это стратегический ресурс».

Eurasianet. https://bit.ly/3aFDB6E 
